\title{
TINGKAT DEPRESI MEMPENGARUHI KEMANDIRIAN ACTIVITY DAILY LIVING (ADL) LANSIA
}

\author{
Reno Tyas Sedyo Arum, Mulyaningsih \\ Sekolah Tinggi Ilmu Kesehatan 'Aisyiyah Surakarta \\ ningsih.solo@gmail.com
}

\begin{abstract}
ABSTRAK
Latar belakang: Berdasarkan data dari BPS (2011) perkiraan jumlah dan proporsi penduduk lansia pada tahun 2011 di Indonesia telah mencapai 18,27 juta. Seiring dengan hal ini, permasalahan pada lansia juga semakin kompleks. Hal ini dikarenakan proses penuaan yang dialami oleh lansia yang diikuti dengan kemunduran fisik dan mental. Kemunduran pada kedua aspek tersebut dapat berdampak pada terjadinya depresi pada lansia. Dari hasil studi pendahuluan, 6 dari 10 lansia mengalami depresi dan 5 dari 10 lansia mengalami ketergantungan. Tujuan; Menganalisis hubungan tingkat depresi dengan kemandirian Activity Daily Living (ADL) pada lansia di Kelurahan Kadipiro Kecamatan Sambirejo Kabupaten Sragen. Metode; Penelitian analitik korelasi dengan rancangan cross sectional. Tehnik pengambilan sampel menggunakan tehnik random sampling dilakukan dengan mengundi anggota populasi (lottery technique), jumlah sampel sebanyak 126 lansia, instrumen penelitian menggunakan wawancara berdasarkan kuesioner. Analisa bivariat menggunakan uji Kendall Tau. Hasil; Hasil uji bivariat menunjukkan bahwa ada hubungan yang signifikan antara tingkat depresi dengan kemandirian Activity Daily Living (ADL) pada lansia dengan nilai ( $\rho$ value0,000 < 0,05). Kesimpulan; Ada hubungan yang signifikan antara tingkat depresi dengan kemandirian Activity Daily Living (ADL) pada lansia di Kelurahan Kadipiro Kecamatan Sambirejo Kabupaten Sragen.
\end{abstract}

Kata kunci: lansia, tingkat depresi, kemandirian Activity Daily Living (ADL)

\section{ABSTRACT}

Background: Based on data from BPS (2011) the proportions of elderly population in Indonesia has reached 18,27 million. Along with this matter, the complex elderly problems also increase. This is because of the aging process that experienced by the elderly that followed by decrease of physical and mental aspects. Decrease on both of the aspects can impact to the elderly with depression experience. The result of preface study, 6 from 10 elderly have depression experience and 5 from 10 elderly have dependence experience. Objective; Analyze the correlation depression degree with independence of Activity Daily Living (ADL) at elderly in district Kadipiro subdistrict Sambirejo regency Sragen. Method; Analytical correlation research with cross sectional design. Technique of taking samples using random sampling technique with lottery technique, with total samples 126 elderly, instrument of research using an interview based on questionnaire. 


\section{GASTER Vol. XV No. 2 Agustus 2017}

Bivariate analysis using Kendall Tau test. Result; Result of bivariate test show that there is a significant correlation between depression degree with independence of Activity Daily Living $(A D L)$ at elderlywith value ( $\rho$ value $0,000<0,05)$. Conclusion; There is a significant correlation between depression degree with independence of Activity Daily Living $(A D L)$ at elderly in district Kadipiro subdistrict Sambirejo regency Sragen.

Keywords: elderly, depression degree, independence of Activity Daily Living (ADL)

\section{A. PENDAHULUAN}

Indonesia merupakan salah satu Negara berkembang dengan tingkat perkembangan yang cukup baik. Kemajuan ilmu dan teknologi di bidang kesehatan dengan cepat mampu memperbaiki keadaan demografi suatu Negara termasuk indicator derajat kesehatan dilihat dari angka kematian ibu melahirkan (Infant Mortality Rate) dan umur harapan hidup meningkat (Yuli,2014:2).

Umur harapan hidup menjadi salah satu indikator keberhasilan pembangunan terutama di bidang kesehatan. Bangsa yang sehat ditandai dengan semakin panjangnya umur harapan hidup penduduknya. Umur harapan hidup penduduk Indonesia mengalami kenaikan setiap tahunnya. Pada tahun 20002005 umur harapan hidup penduduk Indonesia mencapai 68,1 tahun, meningkat pada tahun 2005-2010 mencapai 69,6 tahun, tahun 20102015 meningkat menjadi 70,7 tahun dan pada tahun 2015-2020 proyeksi umur harapan hidup penduduk Indonesia mencapai 71,7 tahun. Peningkatan umur harapan hidup berdampak pada meningkatnya jumlah penduduk lansia dari tahun ke tahun (Pusat Data dan Informasi Kementrian Kesehatan RI 2012).

Jumlah penduduk lansia di Indonesia cenderung meningkat dari tahun ke tahun. Pada tahun 1971 jumlahnya 5,3 juta, kemudian meningkat menjadi 12,7 juta pada tahun 1990 dan diperkirakan 30 tahun berikutnya akan mencapai 28,8 juta (Atun, 2010 : 1). Berdasarkan data dari Badan Pusat Statistik (2011) perkiraan jumlah dan proporsi penduduk lansia pada tahun 2011 jumlah penduduk lansia Indonesia telah mencapai 18,27 juta orang atau sekitar 7,58 persen dari seluruh penduduk Indonesia Semakin tingginya jumlah penduduk lansia ini menjadi tantangan bagi tercapainya kesejahteraan hidup mereka yang selama ini masih sangat jauh dari sejahtera (Atun, $2010: 2$ ).

Kesejahteraan hidup berkaitan dengan taraf kesehatan jiwa dan pemenuhan kebutuhan spiritual (keagamaan) lansia. Pada usia senja 
setiap individumengalamiproses penuaan(aging process) yang merupakan suatu proses alami yang tidak dapat dielakkan dan berpengaruh terhadap segi kehidupan fisik, mental, social maupun spiritual (Hawari, 2007 : 2).

Proses penuaan yang dialami lansia tidak hanya berpengaruh pada segi kehidupan tetapi juga akan diikuti dengan kemunduran fisik dan mental. Kemunduran tersebut dapat berdampak pada terjadinya depresi pada lansia. Tingkat depresi itu sendiri berbeda-beda pada setiap lansia. Hal ini didukung dengan hasil penelitian Riannisa, Lukman \& Hidayati (2014) dari 95 responden lansia, didapatkan hasil sebanyak 42\% mengalami depresi. Dimana sebanyak $24 \%$ mengalami depresi ringan, 11\% mengalami depresi sedang, dan $7 \%$ depresi berat.

Gangguan mental yang sering dijumpai pada lansia adalah kecemasan dan depresi serta gangguan faal tubuh (Hawari, 2007 : 15). Adanya gangguan mental yang terjadi pada lansia dapat mempengaruhi tingkat kemandirian lansia. Hal ini didukung dengan hasil penelitian Lestari, Wihastuti \& Rahayu (2013) dimana terdapat hubungan yang signifikan antara tingkat kecemasan dan tingkat kemandirian pada lansia. Dari 84 responden yang diteliti didapatkan hasil bahwa sebagian besar responden tidak merasa cemas yaitu sebanyak 33 responden (39,3\%) sedangkan untuk tingkat kemandirian, sebagian besar responden mengalami ketergantungan ringan yaitu sebanyak 34 responden (40,5\%).

Selain gangguan mental, terdapat hal-hal lain yang mempengaruhi kemandirian lansia. Hal ini didukung dengan hasil penelitian Jumita, Azrimaidaliza \& Machmud (2012) dari 90 responden sebagian besar dapat melakukan aktivitas secara mandiri 87,78\% dan dipengaruhi oleh kondisi yang sehat $97,4 \%$, kehidupan beragama yang baik $94,2 \%$, kondisi ekonomi yang mampu 97,6\%, dan dukungan keluarga 95,7\%. Sedangkan usia, jenis kelamin, tingkat pendidikan, aktivitas sosial dan olahraga tidak mempengaruhi kemandirian lansia.

Hasil penelitian Sampelan, Kundre \& Lolong (2015) juga menunjukkan bahwa terdapat hubungan yang sangat nyata antara dukungan keluarga dengan kemandirian lansia. Didapatkan hasil dukungan keluarga dalam keadaan baik $69,8 \%$ dan kemandirian lansia yang sebagian besar termasuk dalam kategori baik yaitu $65,1 \%$. Ketergantungan yang disebabkan berbagai keadaan tersebut terus meningkat setiap tahunnya. 


\section{GASTER Vol. XV No. 2 Agustus 2017}

Pada tahun 2001 angka ketergantungan penduduk usia lanjut sekitar 4,0 (Atun, 2010 :2). Sedangkan Badan Pusat Statistik (2011) menjelaskan bahwa hasil dari data susenas menunjukkan angka rasio ketergantungan penduduk lansia pada tahun 2011 adalah sebesar 12,01. Angka rasio sebesar 12,01 menunjukkan bahwa setiap 100 orang penduduk usia produktif harus menanggung sekitar 12 orang penduduk lansia. Pada tahun 2011, rasio ketergantungan penduduk lansia terhadap usia produktif di daerah perdesaan tercatat sebesar 12,34 sedangkan daerah perkotaan sebesar 11,70. Besarnya rasio ketergantungan penduduk lansia menurut provinsi di Indonesia berkisar antara 2,95-20,06.

Berdasarkan uraian latar belakang diatas rumusan masalah dari penelitian ini adalah "Apakah ada hubungan tingkat depresi dengan kemandirian Activity Daily Living (ADL) pada lansia di Kelurahan Kadipiro Kecamatan Sambirejo Kabupaten Sragen?”. Penelitian ini dilakukan untuk mengetahui hubungan tingkat depresi dengan kemandirian Activity Daily Living (ADL) pada lansia di Kelurahan Kadipiro Kecamatan Sambirejo Kabupaten Sragen.

\section{B. METODE DAN BAHAN}

Metode penelitian ini adalah analitik korelasi dengan pendekatan cross sectional yaitu jenis penelitian yang menekankan pada waktu pengukuran atau observasi data variabel bebas dan terikat dilaksanakan sekaligus pada waktu yang sama. Lokasi ini di Kelurahan Kadipiro, Kecamatan Sambirejo, Kabupaten Sragen. Jumlah sampel yang digunakan pada penelitian ini sebanyak 126 lansia dengan teknik pengambilan sampel secara random sampling. Variabel independent (bebas) dalam penelitian ini adalah tingkat depresi sedangkan variabel dependent (terikat) dalam penelitian ini adalah kemandirian Activity Daily Living (ADL) pada lansia. Instrumen yang digunakan berupa kuesioner tingkat depresi pada lansia Geriatric Depression Scale (GDS)dan alat ukur kemandirian Activity Daily Living (ADL) berupa indeks Katz.

\section{HASIL DAN PEMBAHASAN}

\section{Tingkat depresi pada lansia}

Tabel 1 Distribusi frekuensi tingkat depresi pada lansia di Kelurahan Kadipiro Kabupaten Sragen

\begin{tabular}{clcc}
\hline No & Tingkat Depresi & f & \% \\
\hline 1 & Tidak ada depresi & 46 & 36,5 \\
2 & Depresi ringan & 57 & 45,2 \\
3 & Depresi berat & 23 & 18,3 \\
\hline Total & 126 & 100,0 \\
\hline
\end{tabular}


Berdasarkan tabel 1 dapat diketahui bahwa mayoritas lansia mengalami depresi ringan yaitu sebanyak 57 responden (45,2\%). Depresi merupakan satu masa terganggunya fungsi manusia yang berkaitan dengan alam perasaan yang sedih dan gejala penyertanya, termasuk perubahan pada pola tidur dan nafsu makan, psikomotor, konsentrasi, kelelahan, rasa putus asa dan tak berdaya, serta gagasan bunuh diri (Azizah, 2011 : 66). Hal ini berarti lansia di Kelurahan Kadipiro Kecamatan Sambirejo Kabupaten Sragen masih dapat mengontrol alam perasaan mereka, masih dapat berkonsentrasi, memiliki semangat hidup serta merasa dirinya masih berguna. Mayoritas lansia yang mengalami depresi ringan ini dapat dipengaruhi oleh berbagai faktor keadaan seperti kondisi lansia yang sehat, usia, dukungan keluarga yang baik, interaksi sosial dengan tetangga sekitar yang masih terjalin dengan baik serta lansia-lansia yang masih memiliku tingkat spiritualitas yang tinggi.

Hasil penelitian ini didukung oleh penelitian Astuti (2011) dimana hasil penelitian tersebut menunjukkan bahwa sebagian besar responden mengalami depresi ringan yaitu sebanyak 51 responden (83,60\%). Penelitian Riannisa et al. (2014) diperoleh $42 \%$ responden mengalami depresi dan 24\% diantaranya mengalami depresi ringan. Penelitian Muna (2013) menyatakan bahwa dari 40 responden, 24 diantaranya (60\%) mengalami depresi. Sedangkan penelitian Saputri \& Indrawati (2011) menunjukkan hasil bahwa sebagian besar tingkat depresi pada lanjut usia berada pada kategori tinggi.

Pada penelitian Parasari \& Lestari (2015) menunjukkan hasil sebagian besar responden tidak depresi yaitu sebanyak 83,7\%. Penelitian Kristyaningsih (2011) juga menunjukkan hasil bahwa sebagian besar responden tidak ada depresi yaitu 76 responden $(79 \%)$.

Tingkat depresi tersebut dapat dipengaruhi oleh beberapa faktor. Lansia yang hidup sendiri, hidup sebagai janda atau duda cenderung mengalami kemurungan dan kesedihan. Hal ini didukung dengan teori. Menurut Azizah (2011 : 69-71) kehilangan orang yang 
dicintai, kehilangan pekerjaan/jabatan dapat jatuh dalam kesedihan yang mendalam hingga dapat mengalami depresi. Seseorang yang memiliki iman yang kuat dan kehidupan beragama yang baik lebih dapat mengontrol alam perasaan mereka sendiri.

\section{Kemandirian Activity Daily Living} (ADL) pada lansia

Tabel 2 Distribusi frekuensi tingkat kemandirian ADL pada lansia di Kelurahan Kadipiro Kabupaten Sragen

\begin{tabular}{llcc}
\hline No & $\begin{array}{c}\text { Kemandirian Activity Daily } \\
\text { Living (ADL) }\end{array}$ & f & \% \\
\hline 1 & Mandiri & 57 & 45,2 \\
2 & Ketergantungan ringan & 37 & 29,4 \\
3 & Ketergantungan sedang & 22 & 17,5 \\
4 & Ketergantungan berat & 9 & 7,1 \\
5 & Ketergantungan penuh & 1 & 0,8 \\
\hline Total & 126 & 100,0 \\
\hline
\end{tabular}

Berdasarkan tabel 2 dapat diketahui bahwa mayoritas lansia dapat melakukan aktivitas secara mandiri tanpa bantuan yaitu sebanyak 57 responden $(45,2 \%)$. Menurut Maryam et al. (2008 : 174) Setiap individu dalam melakukan kehidupan sehari-hari diusahakan untuk melakukan secara mandiri. Kemandirian tersebut merupakan keadaan tanpa pengarahan, pengawasan atau bantuan orang lain dalam melakukan aktivitas sehari-hari.
Mayoritas lansia yang masih mandiri ini dapat disebabkan oleh berbagai faktor keadaan seperti keadaan kesehatan lansia yang masih baik, dukungan keluarga yang baik, serta usia lansia yang mayoritas masih dibawah 80 tahun.

Hasil penelitian yang mendukung yaitu penelitian Seran (2016) yang menunjukkan sebanyak 21 repsonden $(60,0 \%)$ masih mandiri total. Penelitian Romadlani (2013) juga menunjukkan hasil pada tingkat kemandirian, sebagian besar lansia masih mandiri yaitu 33 lansia $(57,9 \%)$. Selain itu, penelitian Sampelan et al. (2015) menunjukkan hasil mayoritas lansia memiliki tingkat kemandirian yang baik yaitu sebanyak 41 lansia $(65,1 \%)$. Sedangkan hasil penelitian Cahyono (2013) menunjukkan hasil sebagian besar responden mengalami ketergantungan berat yaitu sebanyak 21 responden (39\%). Penelitian Lestari et al. (2013) menunjukkan hasil sebagian besar responden mengalami ketergantungan ringan sebanyak 34 responden (40,5\%).

Beberapa faktor keadaan dapat mempengaruhi kemandirian seseorang dalam melakukan aktivitas sehari-hari. 
Hasil penelitian Jumita et al. (2012) menyatakan faktor yang berhubungan dengan kemandirian lansia adalah kondisi yang sehat, kehidupan beragama yang baik, kondisi ekonomi yang mampu, dan dukungan keluarga.

\section{Hubungan Tingkat Depresi dan} Kemandirian Activity Daily Living (ADL) pada Lansia

Tabel 3. Hubungan tingkat depresi dengan kemandirian ADL pada lansia di Kelurahan Kadipiro Kabupaten Sragen

\begin{tabular}{|c|c|c|c|c|c|c|}
\hline \multirow[b]{2}{*}{ Variabe } & & \multicolumn{3}{|c|}{ Tingkat Depresi } & \multirow[b]{2}{*}{ Total } & \multirow[b]{2}{*}{${ }_{\text {value }} \tau$} \\
\hline & & $\begin{array}{l}\text { Tidak } \\
\text { ada } \\
\text { depresi }\end{array}$ & $\begin{array}{l}\text { Depresi } \\
\text { ringan }\end{array}$ & $\begin{array}{l}\text { Depresi } \\
\text { berat }\end{array}$ & & \\
\hline \multirow{5}{*}{$\begin{array}{l}\text { Keman- } \\
\text { dirian } \\
\text { ADL } \\
\text { pada } \\
\text { lansia }\end{array}$} & Mandiri & $\begin{array}{c}27 \\
(21,4 \%)\end{array}$ & $\begin{array}{c}29 \\
(13,4 \%)\end{array}$ & $\begin{array}{c}1 \\
(0,7 \%)\end{array}$ & $\begin{array}{c}57 \\
(45,2 \%)\end{array}$ & \multirow{5}{*}{$\begin{array}{lll}0,001 & 0,418\end{array}$} \\
\hline & $\begin{array}{l}\text { Ketergan- } \\
\text { tungan } \\
\text { ringan }\end{array}$ & $\begin{array}{c}18 \\
(14,2 \%)\end{array}$ & $\begin{array}{c}14 \\
(11,1 \%)\end{array}$ & $\begin{array}{c}5 \\
(3,9 \%)\end{array}$ & $\begin{array}{c}37 \\
(29,3 \%)\end{array}$ & \\
\hline & $\begin{array}{l}\text { Ketergan- } \\
\text { tungan } \\
\text { sedang }\end{array}$ & $\begin{array}{c}1 \\
(0,7 \%)\end{array}$ & $\begin{array}{c}11 \\
(8,7 \%)\end{array}$ & $\begin{array}{c}10 \\
(7,9 \%)\end{array}$ & $\begin{array}{c}22 \\
(17,4 \%)\end{array}$ & \\
\hline & $\begin{array}{l}\text { Ketergan- } \\
\text { tungan } \\
\text { berat }\end{array}$ & $\begin{array}{c}0 \\
(0,0 \%)\end{array}$ & $\begin{array}{c}2 \\
(1,5 \%)\end{array}$ & $\begin{array}{c}6 \\
(4,7 \%)\end{array}$ & $\begin{array}{c}9 \\
(7,1 \%)\end{array}$ & \\
\hline & $\begin{array}{l}\text { Ketergan- } \\
\text { tungan } \\
\text { penuh }\end{array}$ & $\begin{array}{c}0 \\
(0,0 \%)\end{array}$ & $\begin{array}{c}0 \\
(0,0 \%)\end{array}$ & $\begin{array}{c}1 \\
(0,7 \%)\end{array}$ & $\begin{array}{c}1 \\
(0,7 \%)\end{array}$ & \\
\hline Total & & $\begin{array}{c}46 \\
(36,5 \%)\end{array}$ & $\begin{array}{c}57 \\
(45,2 \%)\end{array}$ & $\begin{array}{c}23 \\
(18,2 \%)\end{array}$ & $\begin{array}{c}126 \\
(100,0 \%)\end{array}$ & \\
\hline
\end{tabular}

Berdasarkan tabel 3 dapat diketahui bahwa responden yang mandiri dan tidak ada depresi adalah sebanyak 27 (21,4\%) sedangkan responden yang ketergantungan penuh dan depresi berat adalah 1 responden $(0,7 \%)$.Depresi adalah bentuk gangguan pada alam perasaan (mood), yang ditandai dengan kemurungan, kelesuan, ketidakgairahan hidup, perasaan tidak berguna, dan putus asa (Hawari, 2007 : 17).

Proses penuaan yang terjadi pada lansia mengakibatkan terjadinya penurunan termasuk juga masalah mental seperti kecemasan dan depresi. Hal ini didukung oleh penelitian Lestari et al. (2013) dimana terdapat hubungan yang signifikan antara tingkat kecemasan dan tingkat kemandirian pada lansia. Hasil penelitian Cahyono (2013) juga menyatakan bahwa terdapat hubungan antara tingkat kemandirian lansia dalam melakukan aktivitas sehari-hari dengan tingkat kecemasan. Seseorang lansia dengan tingkat kecemasan yang tinggi cenderung mengalami ketergantungan dalam melakukan aktivitas sehari-hari.

Selain kecemasan, masalah mental yang sering dijumpai pada lansia adalah depresi. Depresi yang terjadi pada lanjut usia adalah dampak negatif kejadian penurunan fungsi tubuh dan perubahan yang terjadi terutama perubahan 


\section{GASTER Vol. XV No. 2 Agustus 2017}

psikososial. Perubahan-perubahan tersebut seringkali menjadi stressor bagi lanjut usia yang membutuhkan adaptasi biologis dan psikologis (Maryam et al. 2008 : 35). Namun, hasil penelitian Mahfiroh (2013) menyatakan tidak terdapat hubungan pola aktivitas dengan tingkat stress pada lansia.

Seiring dengan bertambahnya usia seseorang, semakin terjadi penurunan pada fungsi-fungsi tubuh. Tidak hanya penurunan pada fungsi fisik saja tetapi juga penurunan mental. Semakin tua, seorang lansia akan banyak memiliki beban pikiran. Mereka cenderung memikirkan masa depan mereka, masa depan anakanak, cucu-cucu dan keluarga mereka. Seperti halnya khawatir akan masa depan, takut pada kematian, memikirkan nasib mereka yang tidak memiliki pekerjaan karena sudah pensiun. Banyaknya beban yang ada dalam pikiran seorang lansia akan mengakibatkan terganggunya fungsi yang berkaitan dengan alam perasaan yang sedih dan gejala penyertanya, termasuk perubahan pada pola tidur dan nafsu makan, psikomotor, konsentrasi, kelelahan, rasa putus asa dan tak berdaya, serta gagasan bunuh diri (Azizah, 2011 : 66).

Rasa putus asa, tidak berdaya, merasa sudah tidak berguna lagi mengakibatkan seseorang kehilangan gairah hidup. Mereka cenderung mengurung diri mereka sendiri dari orang lain, suka menyendiri, kurang berinteraksi dengan dunia luar karena mereka merasa bahwa kehadiran mereka sudah tidak diharapkan dan tidak membawa pengaruh bagi orang lain. Sehingga dalam melakukan aktivitasnya, lansia merasa bahwa mereka sudah tidak mampu memenuhi kebutuhan dasar secara mandiri.

Seseorang dapat dikatakan mandiri dalam melakukan aktivitas biasanya berada dalam kondisi kesehatan yang baik. Hal ini didukung oleh penelitian Jumita et al. (2012) yang menyatakan faktor yang berhubungan dengan kemandirian lansia memperoleh hasil sebagian besar lansia mandiri berada pada kondisi kesehatan yang baik. Sebagian besar dapat melakukan aktivitas secara mandiri dan dipengaruhi oleh kondisi yang sehat, kehidupan beragama yang baik, kondisi ekonomi yang mampu, dan dukungan keluarga. Sedangkan usia, jenis kelamin, tingkat pendidikan, aktivitas sosial dan olahraga tidak mempengaruhi kemandirian lansia. Selain itu, hasil penelitian Ismail (2015) menyatakan bahwa terdapat pengaruh signifikan dari usia, kondisi kesehatan, 
kondisi sosial dan kondisi ekonomi terhadap kemandirian lansia.

Dengan kondisi kesehatan yang baik mereka dapat melakukan aktivitas apa saja tanpa memerlukan bantuan atau sedikit bergantung pada orang lain. Sedangkan responden yang tergantung, mereka tidak dapat melakukan aktivitas sendiri, mereka harus dibantu orang lain, dan bahkan sebagian lansia sama sekali tidak dapat melakukan aktivitas seharihari.Adanya gangguan kesehatan dapat mempengaruhi kemandirian pada lansia. Hal ini didukung dengan hasil penelitian Seran (2016) yang menyatakan bahwa ada hubungan antara nyeri gout arthritis dengan kemandirian lansia. Lansia yang mengalami nyeri cenderung memerlukan bantuan dalam melakukan aktivitas seharihari mereka karena terganggu dengan nyeri yang dirasakannya. Sedangkan hasil penelitian Romadlani (2013) menyatakan bahwa terdapat hubungan antara dukungan keluarga dengan konsep diri, namun tidak ada hubungan antara konsep diri dengan kemandirian lansia.

Adanya dukungan dari orang lain dapat mempengaruhi kemandirian lansia dalam melakukan aktivitas sehari-hari. Hasil penelitian Sampelan et al. (2015) juga menunjukkan bahwa terdapat hubungan yang sangat nyata antara dukungan keluarga dengan kemandirian lansia. Didapatkan hasil sebagian dukungan keluarga dalam keadaan baik dan kemandirian lansia yang sebagian besar termasuk dalam kategori baik.

Berdasarkan hasil penelitian yang menyebutkan bahwa tingkat depresi berhubungan dengan kemandirian Activity Daily Living (ADL) pada lansia dapat disimpulkan bahwa semakin berat tingkat depresi maka lansia tersebut akan mengalami ketergantungan dalam melakukan aktivitas sehari-hari, dan sebaliknya apabila seorang lansia tidak mengalami depresi akan dapat melakukan aktivitas sehari-hari secara mandiri. Hal tersebut dapat terjadi karena lansia yang mempunyai kondisi kesehatan yang baik, baik kesehatan fisik maupun mental maka lansia dapat melakukan aktivitas seharihari secara mandiri.

\section{SIMPULAN DAN SARAN}

Hasil penelitian menunjukkan bahwa lansia di Kelurahan Kadipiro Kecamatan 


\section{GASTER Vol. XV No. 2 Agustus 2017}

Sambirejo Kabupaten Sragen sebagian besar mengalami depresi ringan dan masih dapat melakukan Activity Daily Living (ADL) secara mandiri. Berdasarkan hasil analisis dinyatakan bahwa ada hubungan yang signifikan antara tingkat depresi dengan kemandirian Activity Daily Living (ADL) pada lansia di Kelurahan Kadipiro Kecamatan Sambirejo Kabupaten Sragen.

Berdasarkan hasil penelitian ini maka peneliti menyarankan kepada lansia untuk dapat mencegah terjadinya depresi agar dapat mempertahankan kemandirian dalam melakukan aktivitas sehari-hari. Kemudian untuk tenaga kesehatan supaya dapat memberikan program-program pelayanan kesehatan bagi lansia, seperti posyandu lansia. Sehingga dapat meningkatkan kesehatan lansia, serta dapat menghindari terjadinya depresi dan mempertahankan kemandirian Activity Daily Living (ADL) pada lansia di Kelurahan Kadipiro.

\section{DAFTAR PUSTAKA}

Astuti. 2011. Hubungan Dukungan Keluarga dengan Tingkat Depresi pada Lansia di Posyandu Sejahtera GBI Setia Bakti Kediri. Jurnal STIKES Baptis Kediri. Volume 3, Nomor 2.

Atun. 2010. Lansia Sehat \& Bugar:Pedoman Merawat dan Mendampingi Orang Lanjut Usia. Bantul : Kreasi Wacana.

Azizah. 2011. Keperawatan Lanjut Usia. Yogyakarta : Graha Ilmu.

Badan Pusat Statistik. 2011. Statistik Penduduk Lanjut Usia Indonesia 2011.

Cahyono. 2013. Hubungan Tingkat Kemandirian Lansia dalam Melakukan Aktivitas Sehari-hari dengan Tingkat Kecemasan. Jurnal AKP. Volume 8, Nomor 1.

Hawari. 2007. Sejahtera di Usia Senja Dimensi Psikoreligi pada Lanjut Usia (Lansia). Jakarta: FKUI.

Jumita, Azrimaidaliza, Machmud. 2012. Faktor-faktor yang Berhubungan dengan Kemandirian Lansia di Wilayah Kerja Puskesmas Lampasi Kecamatan Payakumbuh Utara.Jurnal Kesehatan Masyarakat. Volume 6, Nomor 2. 
Kristyaningsih. 2011. Hubungan Antara Dukungan Keluarga dengan Tingkat Depresi pada Lansia. Jurnal Keperawatan. Volume 1, Nomor 1.

Lestari, Wihastuti, Rahayu. 2013. Hubungan Tingkat Kecemasan dengan Tingkat Kemandirian Activity Daily Living (ADL) pada Lanjut Usia di Panti Werdha. Jurnal Ilmu Keperawatan. Volume 1, Nomor 2.

Maryam, Ekasari, Rosidawati, Jubaedi, Batubara. 2008. Mengenal Usia Lanjut dan Perawatannya. Jakarta : Salemba Medika.

Muna. 2013. Hubungan Antara Karakterisitik dengan Kejadian Depresi pada Lansia di Panti Werda Pelkris Pengayoman Kota Semarang. Jurnal Ilmu Keperawatan. Volume 2, Nomor 2.

Parasari, Lestari. 2015. Hubungan Dukungan Sosial Keluarga dengan Tingkat Depresi pada Lansia di Kelurahan Sading. Jurnal Psikologi Udayana. Volume 2, Nomor 1.

Pusat Data dan Informasi Kementrian Kesehatan RI. 2012. Situasi dan Analisis Lanjut Usia.

Riannisa, Lukman, Hidayati. 2014. Gambaran Tingkat Depresi pada Lansia di Kelurahan Babakan Sari Wilayah Kerja Puskesmas Babakan Sari Kota Bandung. Jurnal Ilmu Keperawatan. Volume 2, Nomor 4.

Romadlani. 2013. Hubungan Dukungan Keluarga dan Kemandirian Lansia dengan Konsep Diri Lansia di Kelurahan Bambankerep Kecamatan Ngaliyan Kota Semarang. Jurnal Keperawatan Komunitas. Volume 1, Nomor 1.

Sampelan, Kundre, Lolong. 2015.Hubungan Dukungan Keluarga Dengan Kemandirian Lansia Dalam Pemenuhan Aktivitas Sehari-hari di Desa Batu Kecamatan Likupang Selatan Kabupaten Minahasa Utara. E-Jurnal Keperawatan. Volume 3, Nomor 2.

Seran. 2016. Hubungan Antara Nyeri Gout Arthritis Dengan Kemandirian Lansia di Puskesmas Towuntu Timur Kecamatan Pasan Kabupaten Minahasa Tenggara. Jurnal Keperawatan. Volume 4, Nomor 1.

Yuli. 2014. Buku Ajar Asuhan Keperawatan Gerontik Aplikasi NANDA, NIC, dan NOC. Jakarta: Trans Info Media. 